\title{
The Effect of Digital Public Relations Campaign on Customer Loyalty (Study on "Self-Love" Campaign in @Pluffyschoice Instagram)
}

\author{
Valenciana Febiola ${ }^{1}$ Daniel Tamburian ${ }^{1 *}$
}

\author{
${ }^{1}$ Faculty of Communication, Universitas Tarumanagara, Jakarta 11440, Indonesia \\ ${ }^{*}$ Corresponding author.Email: danielt@fikom.untar.ac.id
}

\begin{abstract}
The emergence of perceptions in society about the ideal body shape effects most Indonesian women to not love themselves. So, Pluffy's Choice which is a women's clothing fashion brand, is interested in conducting a digital "Self-Love" campaign on their Instagram. Consumer awareness about the campaign has formed and the public's positive perception of Pluffy's Choice will result in an intention to buy the product. This study aims to determine the effect of the digital Public Relations campaign on customer loyalty. The theoretical basis in this research is the Public Relations campaign by Rosady Ruslan and customer loyalty by Giddens. This research uses quantitative approach with survey methods and data collection techniques through questionnaires that distributed online to 100 respondents. The results of the data analysis shows that the independent variable has a very strong relationship and has a significant effect on dependent variable, where the digital Public Relations Self-Love campaign has an effect of $70 \%$ on Pluffy's Choice customer loyalty, while $30 \%$ is another factor that is not examined.
\end{abstract}

\section{Keywords: Digital Campaign, Public Relations, Customer Loyalty, Pluffy's Choice}

\section{INTRODUCTION}

The emergence of perceptions about the ideal body shape or body standardization ideal is happening in many parts of the world, in Indonesia standardization ideal body is a body that has a balance between height and weight body [1]. The ideal body standard for women is to have slim body shape, tall, and shine, smooth, and white skin. When women are unable to achieve this ideal body standard, they will feel shame, dissatisfaction with her body condition, even hating themselves. These feelings can occur due to low body image in a person.

Body image is a people's image of their shape and size. According to Honigam and Castle [2] depicts body image as a mental image of a person towards form and body size, how a person perceives and gives an assessment of what they think and feel about their size and body shape, and on other people's judgments of them. Actually, what is they thought and felt, not necessarily actually presented actual circumstances, but more of a result of self-assessment subjective. Pluffy's Choice is one of the fashion brands that cares about this phenomenon of standardization of this ideal body, so they make digital Public Relationship campaign "Self-Love" to increase women's confidence and want everyone assume that all shapes and sizes of the female body is beautiful. The "Self-Love" campaign is conducted on Pluffy's Choice's Instagram (@pluffyschoice) by uploading content that related to "Self-Love" such as quotes, motivational images, and also a video campaign that aims to motivate or improve women's confidence.

Shimp [3] states that the campaign is effective creating consumer awareness, will encourage the formation of perceptions positive towards the brand and there may be an intention to buy these brands in the future. Based from the lack of brands fashion that produces and sells clothes with various sizes, of course this is related to customer loyalty. In other words, Pluffy's Choice that has gained consumer awareness and a positive public perception will emerge the intention to buy the product. Kriyantono [4] states that the hypodermic needle theory assumes that the components of communication (communicator, message, media) have a tremendous influence in change attitudes and behavior of audiences. So it can be assumed that messages have a strong influence in changing audience attitudes and if the audiences have a positive attitude towards Pluffy's Choice, hence that positive attitude will contribute to changes in public behavior (consumers), which is the existence of loyalty towards Pluffy's Choice product.

Based on the background of the problem that has been described, the formulation problem in this research is "Is the digital Public Relations Self- Love Campaign on Pluffy's Choice can impact customer loyalty?". This research aims to know the relationship between the digital Public Relations campaign on customer loyalty and to determine 
the effect of digital Public Relations campaign on customer loyalty. So that the hypothesis in this research are:

Ho: There is no digital Public Relations campaign effect on loyalty customer

Ha: There is the effect of digital Public Relations campaign on loyalty customer.

\subsection{Related Work}

\subsubsection{Presentation of Research Results by Florentinus Dhanu Nugroho (2010)}

This research was conducted by Florentinus Dhanu Nugroho with title The Effect of Attitude in Campaign Message on Consumer Loyalty (Case: The Body Shop Campaign Message in Influencing Consumer Loyalty to Brands). This research was published in 2010, from Atma Jaya Yogyakarta University. The formulation of the problem in this study is "How is the influence of attitude on campaign messages on consumer loyalty of The Body Shop?". The theories used in this research are Public Relations Campaign, Hypodermic Needle Theory, Attitude Theory, Brand Image, and Consumer Loyalty. This research used a quantitative approach, with an explanative survey and data analysis methods. The result of this research is there is an effect of attitude on campaign messages on consumer loyalty. The results of data analysis show that the attitude of the campaign message has a positive effect on consumer loyalty with brand image as a mediating variable. Attitudes on campaign messages and brand image have an effect of $60.4 \%$ on consumer loyalty. The difference between this research and the research that conducted by the author is that this research was conducted on The Body Shop store, while the author's research was on the online fashion shop. In addition to that, in the author's research is not use the attitude and brand image theory.

\subsubsection{Presentation of Research Results by Visakha Ratna Dewi and Septia Winduwati (2019)}

This research was conducted by Visakha Ratna Dewi and Septia Winduwati with title "Real People Real Body" Women's Positive Body Campaign by @nipplets_official. This research was published in 2019 from Tarumanagara University. The formulation of the problem in this study is "How is the Nipplets campaign, starting from the research, planning, communication, and evaluation stages?". This study uses the theory of Communication, Persuasive Communication, Social Media, Public Relations Campaigns, Body Image, and Cyber Public Relations. This research uses a qualitative descriptive approach, with a case study method. The result of this research shows that the "Real People Real Body" campaign is positive because most of the feedback from this campaign obtained from the results of interviews, Nipplets questionnaires, and comments on the Instagram account @ nipplets_official are all positive. The message conveyed by the Nipplets is well received by the audience and can change women's mind. Through this campaign, Nipplets has also become a sociopsychological support for women who are have not accept his own body yet. The difference between this research and the author's research is this research was conducted used qualitative research methods, while the author's research used quantitative research methods. In addition to that, in the author's research is not use Cyber Public Relations theory.

\subsubsection{Presentation of Research Results by Rosyifa Ulya Masitha and Elisabeth Ananda Eka Bonita (2019).}

This research was conducted by Rosyifa Ulya Masitha and Elisabeth Ananda Eka Bonita with title The Effect of the "SORE" Web Series Digital Campaign on Purchasing Decisions Through the Tropicana Slim Stevia Brand Awareness among Young Adults. This research was published in 2019 on Communication Research Journal, Volume 2, Number 2. The formulation of the problem in this research is "How big is the effect of the digital campaign web series "SORE" on purchasing decisions through the Tropicana Slim Stevia brand awareness among young adults?". The theory in this research is mass communication, diffusion of innovation, digital campaign, and brand awareness. This research uses quantitative methods with an explanatory approach and using a positivism paradigm. Data collection techniques are carried out using a questionnaire method. The final result of this research shows the effect of the digital campaign variable on purchasing decisions, purchasing decisions on brand awareness, and the effect of digital campaigns and purchasing decisions on brands awareness. The difference between this research and the author's research is the digital campaign in this study is through YouTube and this research aims to determine the effect of digital campaigns on purchasing decisions, while the author's research is through Instagram and aims to determine the effect of the digital Public relations campaign on customer loyalty. In addition to that, in the author's research is not use the diffusion of innovation and brand awareness theory.

\subsection{Our Contribution}

This research is expected to contribute to both academic and practical benefits. Academic benefits in this research are expected to provide scientific contributions as a reference for studies on digital Public Relations campaigns and customer loyalty. In addition, this research is also expected to become a new discourse and become a new reference source relating to the issue of digital Public Relations campaigns on customer loyalty. While the practical benefits in this study, it is divided into 3, namely: (1) For the author, it is expected to be a useful tool in implementing the author's knowledge of digital Public Relations campaign on customer loyalty. (2) For future researchers, it is hoped that it can become one of the reference materials for other 
research regarding digital Public Relations campaigns on customer loyalty. (3) For companies, this research is expected to be a source of useful information and input for company management or Pluffy's Choice online shop regarding how much influence the use of digital Public Relations campaigns has on loyalty customers, so that it can be taken into consideration in increasing customer loyalty in the future.

\subsection{Paper Structure}

The rest of the paper is organized as follows. Section 1 introduces the preliminaries used in this paper, which include background and problem formulation. Section 2 presents a theoretical framework and theories that used in this research. Then, in Section 3 explain the methods that used in this research. Section 5 presents findings and discussion about the cases in this research. Finally, Section 6 concludes the paper and presents direction for future research.

\section{BACKGROUND}

In this study, researchers will use digital media theory, Public Relations campaign, and customer loyalty. According to Flew [5], digital media is media that contains a combination of data, text, voice, and various types of images are saved in digital format and distributed via a cable-based broadband optical network, satellite and transmission systems microwaves. Social media (digital media) has changed the world within various things and various industrial fields, one of which is the Public industry Relations where social media is now an effective tool to use by Public Relations practitioners in carrying out their roles and functions, including Public Relations campaign. According to Ruslan [6], Public Relations campaign aims to increase awareness and knowledge target audience so as to foster a positive perception or opinion on activities of an institution or organization in order to create a trust and a good image of the community through the delivery of messages intensively with the communication process within a certain period of time and continuously.

The hypodermic needle theory had profound implications change the attitudes and behavior of the audience [4], so can be assumed that messages have a strong influence in changing attitudes audiences and if audiences have a positive attitude towards Pluffy's campaign Choice, then this positive attitude will later contribute to its occurrence changes in public behavior (consumers), one of which is the existence loyalty/consumer loyalty to Pluffy's Choice products.

Digital Public Relations campaign indicator in this study using indicators of the effectiveness of the digital Public Relations campaign according to Brian Solis [7], which is divided into exposure, engagement, influence, and action. In the exposure stage, the effectiveness of the Public Relations campaign is measured based on how many audiences were exposed to the campaign content created. At the engagement stage, the effectiveness of the Public
Relations campaign concerns on how many actions to take on a campaign message be delivered. In the influence stage, the Public Relations campaign is measured through the extent to which the campaign content created affects perceptions and attitudes audience. Apart from that, it can also be measured by how many audiences there were his perception was successfully changed because of a campaign that was made. At the stage action, the measured aspect has reached the level of behavior. For example, how much many audiences recommend the campaign they created to others. At the exposure stage, the public knows about digital Public Relations Campaign. At the engagement stage, the public began to take action against digital Public Relations campaign. At the influence stage, the public began to be influenced with messages from the digital Public Relations campaign created, and arrived at the last stage is the action where consumers start buying products. Consumers who have bought the product and are satisfied with the product certainly will make repeated purchases of the product, do not want to move to other products, and recommending products to others.

These forms of consumer behavior are indicators to measure loyalty customer. Loyalty is the repetition or selection (purchase) of the same brand in all cases of purchase. Loyalty can be defined as a deep commitment to repurchasing a product or services [8]. Indicators used to measure Customer loyalty in this study is a characteristic of customer loyalty according to Giddens [9], namely: (1) Having a commitment to the brand; (2) Dare to pay more on the brand when compared with other brands; (3) Would recommend the brand to people other; (4) Do not take any consideration when making product repurchases; (5) Always follow the information relating to the brand; (6) Can be a spokesperson for the brand and always develop relationship with the brand. Therefore, it can be assumed that digital Public Relations campaigns are related and can influence loyalty customer.

\section{METHODS}

The approach in this research is a quantitative approach because analyze data statistically. Quantitative method means a research method based on the philosophy of positivism used to research at a population or specific samples, data collection in this study using research instruments, data analysis that is quantitative/statistical, with the aim to describe and test the hypotheses that have been set [10]. The research method used is a survey method, as is explained by Kerlinger [10] that the survey method is research conducted on a large or small population, but data what is studied is the data from the sample taken from the population so we find relative occurrences, distributions, and relationships between sociological and psychological variables. The population in this study were Instagram account followers or followers @ pluffyschoice of 300,000 $\left(1^{\text {st }}\right.$ November 2020). In this research, the sample used is non probability sampling because of opportunity or the opportunity for each element or member of the population selected to be sampled not the same. One sample form of 
non-probability sampling used in this study is a quota sampling technique that aims to determine a sample from a population that has certain characteristics until meet the desired quota [10]. After being calculated using Slovin formula to determine the number of samples, found the results of 100. The data collection technique is done by distributing questionnaires to the samples studied were never seen or read (though at a glance) about the Self-Love campaign also buying and using products from Pluffy's Choice.In this study, the processing technique used test classical assumptions (normality test, linearity test, and heteroscedasticity test), test determination (R square), and hypothesis testing ( $\mathrm{T}$ test) with the help of SPSS software 24.0. The normality test in this study used a one-sample Kolmogrov-Smirnov statistical analysis provided that if the significance is bigger than 0.05 then the residual value is normally distributed [11]. Linearity test in this study was carried out provided that the deviation from linearity significance is bigger than 0.05 , then there is a relationship which is linearly significant between the independent variable and the dependent variable [12]. While the heteroscedasticity test in this study using the Glejser test provided that the significance value is bigger than 0.05 , then there are no symptoms of heteroscedasticity in the regression model [13]. For the test of determination using the interpretation table of the $\mathrm{R}$ value and for the test Hypothesis ( $T$ test) is carried out with Ho criteria accepted if the $t$-value $<t$-table or a significance value $>0.05$. If there is acceptance of Ho, it can be concluded that there is no significant effect, whereas if Ho is rejected, it means there is significant effect. Data analysis in this study is to use simple linear regression analysis. The data validity technique in this study is to use the test validity, which is done by correlating the score of the item with the total score. Question items from the questionnaire are declared valid if $r$ count $>r$ table. In addition, the validity technique in this study is the reliability test with using the Cronbach Alpha statistical test. Criteria for an instrument to be said to be reliable if the value obtained in the testing process by testing Cronbach Alpha statistics is bigger than 0.60 [14].

\section{FINDINGS AND DISCUSSIONS}

In this study, online questionnaires were distributed to 100 respondents. The majority are women at $98 \%, 89 \%$ aged $17-$ 26 years, and their occupation are students and private employees with percentages of $49 \%$ and $34 \%$, which in accordance with this study that standardization of the ideal body occurs in many adolescent and adult women. From the results of the validity test, it was found that each item was Digital Public Relations Campaign (X) and Customer Loyalty (Y) are declared valid because $r$ count $>r$ table. Likewise with the reliability test results, the test results against variable Digital Public Relations Campaign (X) and Customer Loyalty (Y) indicates that the Cronbach Alpha value is bigger than 0.60 . Hence, it can be determined that the instrument in this study is reliable. The classic assumption test in this study, namely the normality test, linearity test, and heteroscedasticity test. The results of the normality test in this study obtained numbers probability or Asymp. Sig. (2-tailed) of 0.098. Then the value can be expressed residuals are normally distributed because $0.098>$ 0.05. Linearity test results in this study, the value of deviation from linearity Sig. amounting to $0.599>0.05$, it can be concluded that there is a significant linear relationship between variable Digital Public Relations Campaign with Customer Loyalty. Whereas for the heteroscedasticity test, a significance value (Sig.) was obtained of 0.103 which means the significance value > 0.05 . It can be concluded that there is no symptom of heteroscedasticity in the regression model. To test and find out how much the effect between digital Public Relations campaign on customer loyalty in research. In this case, a simple linear regression analysis was performed. Simple linear regression test results in this study are as follows:

Table 1. Simple Linear Regression Test Results

\section{Coefficients $^{\mathbf{a}}$}

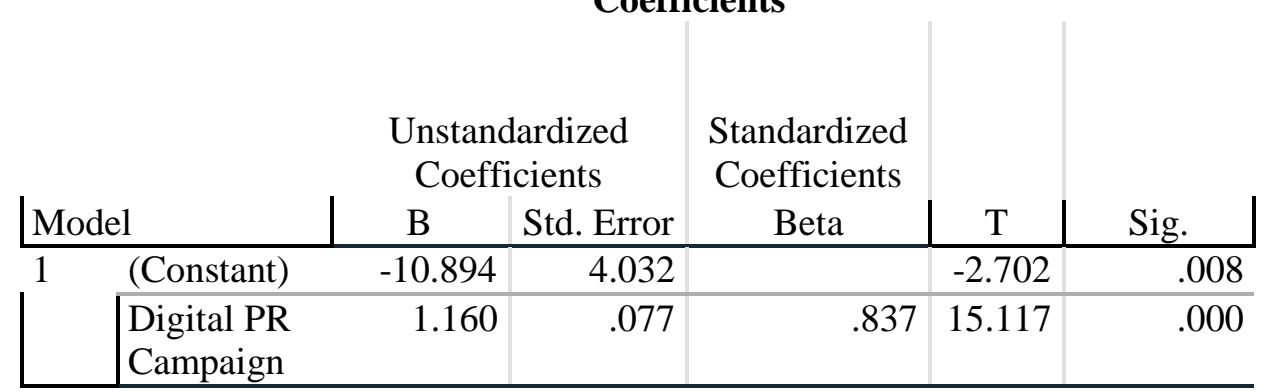

a. Dependent Variable: Customer Loyalty

Source: Researcher's Documentation (2020)

Based on the table 1, the regression equation model is obtained:

$Y=-10,894+1,160 X$

Where:

$\mathrm{Y}=$ Customer Loyalty

$\mathrm{X}=$ Digital Public Relations Campaign (Self-Love)
The coefficients of the simple linear regression equation above can be interpreted as a constant regression coefficient of -10.894 which indicates that if the digital variable Public Relations campaign has a value of 0 , customer loyalty is negative $(-10,894)$. While the customer loyalty variable is 1,160 shows that every $1 \%$ increment of digital Public 
Relations rate campaign, then customer loyalty will increase by 1,160 .

Table 2. Hypothesis Test Results (T Test)

\section{Coefficients $^{\text {a }}$}

\begin{tabular}{|c|c|c|c|c|c|}
\hline \multirow[b]{2}{*}{ Model } & \multicolumn{2}{|c|}{$\begin{array}{c}\text { Unstandardized } \\
\text { Coefficients }\end{array}$} & \multirow{2}{*}{$\begin{array}{c}\text { Standardized } \\
\text { Coefficients } \\
\text { Beta } \\
\end{array}$} & \multirow[b]{2}{*}{$\mathrm{T}$} & \multirow[b]{2}{*}{ Sig. } \\
\hline & $\mathrm{B}$ & Std. Error & & & \\
\hline (Constant) & -10.894 & 4.032 & & -2.702 & .008 \\
\hline $\begin{array}{l}\text { Digital PR } \\
\text { Campaign }\end{array}$ & 1.160 & .077 & .837 & 15.117 & .000 \\
\hline
\end{tabular}

a. Dependent Variable: Customer Loyalty

Source: Researcher's Documentation (2020)

Based on the data above, the result is that the independent variable (digital Self-Love campaign) has a significant effect on the dependent variable (loyalty customer). This is indicated by the results of the Partial Effect Significance Test ( T Test) which is less than $0.05(0.000<0.05)$ which means that there is an influence between the digital Public
Relations campaign and customer loyalty. When viewed based on t count, it is found that the results of $t$ count $>t$ table $(15,117>1,984)$. Based on these criteria, Ho is rejected and $\mathrm{Ha}$ is accepted, which means digital Public Relations campaign has a significant effect on customer loyalty.

Table 3. Determination Test Result Model Summary

\begin{tabular}{|c|c|c|c|c|}
\hline \multirow[b]{2}{*}{ Model } & \multirow[b]{2}{*}{$\mathrm{R}$} & \multicolumn{2}{|r|}{ ivodel summary } & \multirow[b]{2}{*}{ Std. Error of the Estimate } \\
\hline & & R Square & Adjusted R Square & \\
\hline 1 & $.837^{\mathrm{a}}$ & .700 & .697 & 7.46741 \\
\hline
\end{tabular}

a. Predictors: (Constant), Digital PR Campaign

Source: Researcher's Documentation (2020)

Through the results of the determination test in the table above, the $\mathrm{R}$ value is obtained is a symbol of the coefficient which is equal to 0.837 , which means that it occurs very strong relationship between digital public relations campaign and loyalty customer. With a determination coefficient of $70 \%$, it has a positive effect, which means that the higher the digital Public Relations campaign that is made the higher the Pluffy's Choice customer loyalty. While $30 \%$ is a factor that affects customer loyalty than other factors that are not researched in this study. Based on respondents' answers received through a questionnaire distributed, it can be concluded that some respondents agree with it the effect of the digital Public Relations Self-Love campaign on customer loyalty Pluffy's Choice. According to Brian Solis [7] there are four indicators as tools to measure the effectiveness of digital campaigns, namely exposure engagement, influence, and action. From the results of the data obtained based on the answers respondent, the answer to variable $\mathrm{X}$ (digital Public Relations campaign Self-Love) most of the respondents answer strongly agree and agree, so it can be concluded that digital Public Relations Self-Love campaign that created by Pluffy's Choice is effective in building customer loyalty. According to Giddens, the characteristics of consumer loyalty to the brands, namely: (1) Having a commitment to the brand;(2) Dare to pay more on the brand when compared with other brands;(3) Would recommend the brand to people other;(4) Do not take into account when making product repurchases the; (5) Always follow the information relating to the brand;(6) Can be a spokesperson for the brand and always develop relationship with the brand [9]. From the results of the respondents' answers, most respondents answered strongly agree and agree with the characteristics of consumer loyalty, so it can be concluded that the digital Public Relations campaign has an effect on customer loyalty. Through data from respondents' answers to the digital Public Relations indicator campaign, the results obtained that as many as $68 \%$ and $27 \%$ of the number of respondents who answered strongly agree and agreed that they changed their perception regarding the ideal body shape after seeing the Self-Love campaign. Aside from that, the results showed that as many as $46 \%$ and $50 \%$ who answered strongly agree and agreed that they became more confident after seeing the Self- Love campaign. The results showed that $60 \%$ and $35 \%$ respondents answered strongly agree and agree that they love themselves more upon seeing Self-Love campaign. In addition to that, from the respondents' answers for the loyalty indicator customers, the results show that as many as $35 \%$ and $32 \%$ of the total respondents who answered strongly agreed and agreed that they were influenced by digital Public Relations Self-Love campaign that created by Pluffy's Choice and decided to buy a product at Pluffy's Choice. In addition to that, it is also obtained as many as $37 \%$ and $28 \%$ who answered strongly agree and agree to support Self-Love campaign by continuing to use Pluffy's Choice products. Continue using 
a product in one particular brand is one form commitment to the brand which is a characteristic of consumer loyalty. So, from the results of the data analysis, Pluffy's Self-Love campaign Choice can be said success because the goal of this campaign can be achieved, which is increase the confidence of every woman so that she can buy the product at Pluffy's Choice and become loyal to Pluffy's Choice. Apart from that, from the results analysis of the data can also be concluded that digital Public Relations campaign that created by Pluffy's Choice has very strong impact towards customer loyalty.

\section{CONCLUSIONS}

Based on the results of research and discussion that has been done by the author regarding "The Effect of the Digital Public Relations Campaign on Loyalty Customers (Study on the Self-Love Pluffy's Choice Campaign on Instagram (a) Pluffy's Choice)", the writer draws the conclusion that digital variables Public Relations Self-Love campaign has a very strong relationship with customer loyalty variable. In addition, the $\mathrm{R}$ square value is also obtained of 0.700 (70\%). This shows that the percentage of the contribution of the influence of the independent variable (digital Public Relations campaign) to the dependent variable (customer loyalty) is by $70 \%$. While the remaining $30 \%$ is influenced by other variables not examined in this study. Based on the results of the T-Test, The Digital Public Relations SelfLove campaign has a significant effect towards customer loyalty because $\mathrm{Ho}$ is rejected and $\mathrm{Ha}$ is accepted which means that there is the significant influence between the digital Public Relations Campaign on Pluffy's Choice customer loyalty.

\section{ACKNOWLEDGMENT}

Special thanks are given to the Faculty of Communication, Tarumanagara University, Mr. H. H. Daniel Tamburian S.Sos., M.Si. as a lecturer supervisors, family, friends, and respondents who have help and support so this research can be on time completed.

\section{REFERENCES}

[1] Sakinah, Ini Bukan Lelucon : Body Shaming, Citra Tubuh, Dampak dan Cara Mengatasinya, Jurnal Emik, vol.1, no.1, pp.54, December 2018. https://ejournals. umma.ac.id/index.php/emik/article/view/41

[2] A. U. Denich and Ifdil, Konsep Body Image Remaja Putri, Konseling dan Pendidikan, vol.3, no.2, pp.56, Juni 2015. https://jurnal.konselingindonesia.com/index.php/ jkp/article/view/165
[3] D. D. Barata, Analisis Keberhasilan Kampanye Iklan dalam Proses Pengambilan Keputusan Memilih Perguruan Tinggi, Ulitima Management, vol.2, no.1, pp.28, Juni 2010. https://ejournals.umn.ac.id/index.php/ manajemen/article/view/167

[4] R. Kriyantono, Teknik Praktis Riset Komunikasi. Jakarta: Kencana, 2006.

[5] D. U. Putri, Peran Media Baru dalam Membentuk Gerakan Sosial (Studi Kasus pada Individu yang Terlibat dalam Indonesiaunite di Twitter. Depok: Indonesia University, 2012

[6] R. Rosady, Kiat dan Strategi Kampanye Public Relation. Jakarta: Rajawali Pers, 2005.

[7] S. Brian, Engage : The Complete Guide for Brands and Businesses to Build, Cultivate, and Measure Success in The New Web. New Jersey: John Wiley \& Sons, 2010.

[8] D. M. Firmansyah, Pemasaran Produk dan Merek: Planning \& Strategy. Pasuruan: Qiara Media, 2019.

[9] F. D. Nugroho, Pengaruh Sikap pada Pesan Kampanye Terhadap Loyalitas Konsumen (Kasus : Pesan Kampanye The Body Shop dalam Mempengaruhi Loyalitas Konsumen terhadap Merek). Yogyakarta: Atma Jaya Yogyakarta University, 2010.

[10] Sugiyono, Metode Penelitian Kuantitatif. Bandung: Alfabeta, 2018.

[11] D. Priyanto, Mandiri Belajar SPSS. Jakarta: PT Buku Kita, 2009.

[12] J. Widiyanto, SPSS for Windows. Surakarta: Publishing Agency FKIP Muhammadiyah University, 2012.

[13] Ghozali, Aplikasi Analisis Multivariate dengan Program IBM SPSS 23, ed.8. Semarang: Publishing Agency Diponegoro University, 2016.

[14] I. N. Dalila, Pengaruh Pola Kepemimpinan Kepala Madrasah dan Pelaksanaan Kurikulum terhadap Kompetensi Pedagogik Guru di MTS Negeri 1 Kudus. Kudus: STAIN Kudus, 2016. 